\title{
Development of Sustainable Gross National Income from Potato Export in Bangladesh- A Perspective Review
}

\author{
Tuhin Suvra Roy ${ }^{1, *}$, Rajesh Chakraborty ${ }^{1}$, Md. Nahid. Parvez ${ }^{2}$, Suvomoy Biswas $^{3}$, Sudip Chakraborty ${ }^{1}$ \\ ${ }^{1}$ Department of Agronomy, Sher-e-Bangla Agricultural University, Bangladesh \\ ${ }^{2}$ Department of Agriculture, Faculty of Agriculture, First Capital University of Bangladesh, Bangladesh \\ ${ }^{3}$ Department of Biochemistry, Sher-e-Bangla Agricultural University, Bangladesh
}

Copyright $\bigcirc 2017$ by authors, all rights reserved. Authors agree that this article remains permanently open access under the terms of the Creative Commons Attribution License 4.0 International License

\begin{abstract}
Potato (Solanum tuberosum L.) in Bangladesh has arisen fast due to economic liberalization coupled with growing urbanization, expanding market options. The potato is considered to be a potential crop to face the challenge of $21^{\text {st }}$ century. It can serve the food security of the ever growing population, creation of job opportunities and developing agro-based and agro-processing industries in the country for sustainable economic growth. Bangladesh achieved a remarkable success in potato production to take it to $7^{\text {th }}$ rank in the world map. Potato production is increasing day by day both vertically and horizontally. In 2014 , total production was 8.6 million tons and the consumption capacity was 6.5 million tons, rest 2.1 million tons was surplus. So need to export potato to foreign countries. But the major constraints for this is non-availability of sufficient suitable varieties with high dry matter $(>21 \%)$ and low reducing sugar content $(<0.01 \%)$. Identification of cropping zones, technology packages for production of export quality varieties, non-availability of resistant varieties for bacterial wilt and technologies for long period storage are other limitations in developing export sectors in the country. To meet the instant need of the processing varieties, the variety introduction procedure may be liberalized under a crush programme to ensure quick inflow of processing varieties in the country. Export of potatoes is an important avenue to expand utilization of potatoes grown in the country.
\end{abstract}

Keywords Consumption, Export, Glut, National Income, Quality, Production, Potato

\section{Introduction}

Potato popularly known as 'The king of vegetables', it is the $4^{\text {th }}$ most important food crop in the world after rice, wheat and maize [1]. Potato is the world's single most important non-cereal crop with a vital role in the global food system. It can be compared only with rice, wheat and maize for its contribution towards securing the food and nutrition and eradicating malnutrition and hunger, especially in developing countries $[2,3]$. Potato crop has the capacity to produce more food per unit time and area and has high nutritional value to sustain burgeoning population. It produces $47.6 \mathrm{~kg}$ of food/ha/day whereas wheat, rice and maize produce 18.1, 12.4 and $9.1 \mathrm{~kg}$ food/ha/day, respectively [4]. Potato is a wholesome food containing carbohydrates $(16 \%)$, protein $(2 \%)$, minerals $(1 \%)$, dietary fibres $(0.6 \%)$ and a good source of vitamin $\mathrm{C}$ and antioxidants. It is a versatile food as it can be cooked in many ways, can be processed into a number of products each having its characteristics tastes and can fit into any meal. There has been a sustained change in potato consumption pattern in most of the developing countries. This is due to increasing population pressure, growing urbanization and fast changing consumers and market preferences [5]. Till date, The Tuber Crops Research Centre, Bangladesh Agricultural Research Institute has released 66 high yielding potato varieties including 'Lady Rosetta', 'Courage' 'Asterix' which have been specifically based for catering to the needs of processing industries. Bangladesh just started to export potato on "Granula" due to its quality standard for export but several potato varieties (Lady Rosetta, Courage and Asterix) are screened as per exportable standard as Granula. With maintaining the national demand of potato consumption now a resilient door is opened for export in abroad. From these perspectives, the present study was aimed to know the status of potato production and consumption for export by meeting the national demands for quality consumption throughout the major potato eating countries.

\section{Materials and Methods}

To make a good format for the present study, the information's were collected from the secondary data 
sources and personal contact with DAE personnel's. After collecting the data, different graph was made by using MS excel spread sheet and different tables were made from literature. No logical framework has been used under present study and no variables were used to analyze importance of different status of production, consumption, surplus and export. Only different secondary data was used to make this article to highlight the importance of potato export through processing industry.

\section{Discussion}

\subsection{Present Status of Potato in Bangladesh}

After rice and wheat, potato is the third largest food crop in Bangladesh. Potato (Solanum tuberosum L.) is one of the major food crops of the world. In Bangladesh, it ranks second after rice in production [1]. The total area under potato crop, per hectare yield and total production in Bangladesh are 0.44 million hectare, 19.37 ton/ha and 8.6 million tons, respectively [6]. The total production is increasing day by day as such consumption also rapidly increasing in Bangladesh [6]. Over the past six decades, a remarkable growth in area, production, and yield of potatoes have taken place in Bangladesh. Potato is one of the most important vegetable crops and having a balanced food containing about 75 to $80 \%$ water, 16 to $20 \%$ carbohydrates, 2.5 to $3.2 \%$ crude protein, 1.2 to $2.2 \%$ true protein, 0.8 to $1.2 \%$ mineral matter, 0.1 to $0.2 \%$ crude fats, $0.6 \%$ crude fiber and some vitamins [7]. It is a staple diet in European countries and its utilization both in processed \& fresh food form is increasing considerably in Asian countries [8]. Moreover, number of processing industries and potato products are increasing with the demand of specific varieties. Besides culinary consumption, the use of potato has progressively increased as a raw material by the processing industry [9]. Now a day, the most important features of potato production is tuber quality [8]. So quality attributes should take into account to fulfill the customers and industry demand. Potato must meet a number of requirements including high dry matter content and good color to fulfill the requirement of processing. Presently there are very few varieties for processing purpose, developed locally, despite the increasing demand of acceptable yield and processing quality. The yield and processing characteristics of available potato genotypes are largely unidentified. Keeping in view the consumers requirement, it is important to identify varieties that possess traits to meet the domestic demand and provide growers the opportunity to meet the challenges of frequently changing market, production circumstances and improving their economic condition by selling their export quality potato at good price to the processing industry both in Bangladesh and abroad [10].

\subsection{Ranking of Bangladesh in the World}

The cumulative success in production of potatoes over the years took Bangladesh to the seventh position in the world as may appear in Fig. 1-4 below.



Figure 1. Global ranking of top 10 countries in production of potatoes (FAOSTAT, 2014)

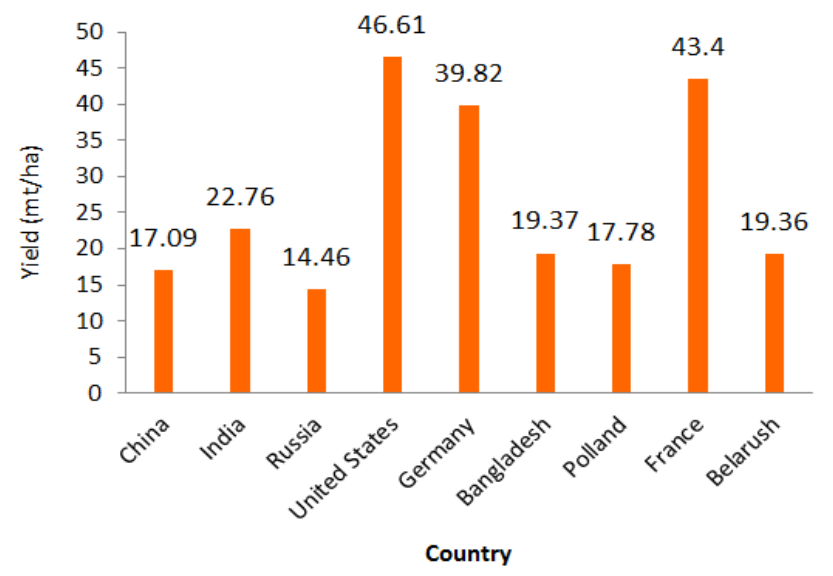

Figure 2. Global ranking of top 10 countries in yield of potatoes (FAOSTAT, 2014)

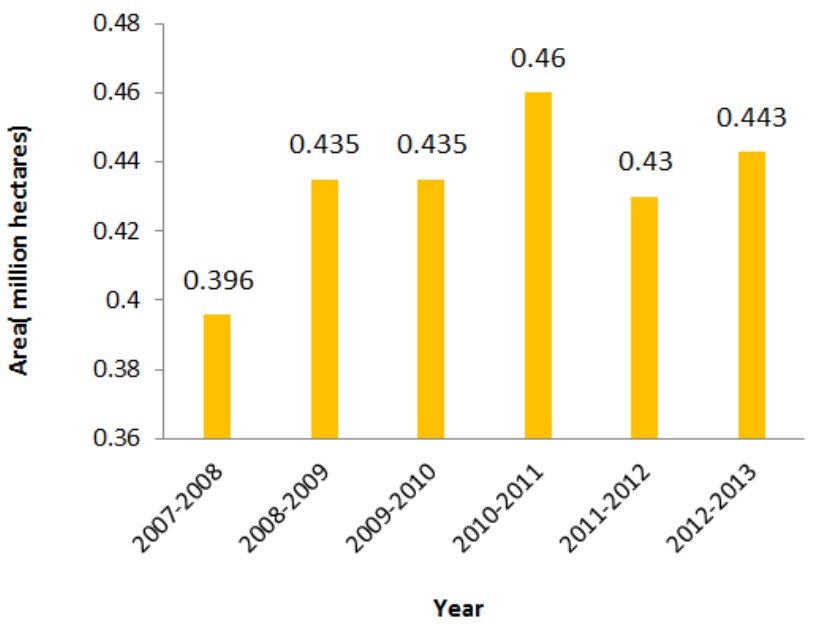

Figure 3. Area harvested for potato in Bangladesh (FAOSTAT, 2014) 


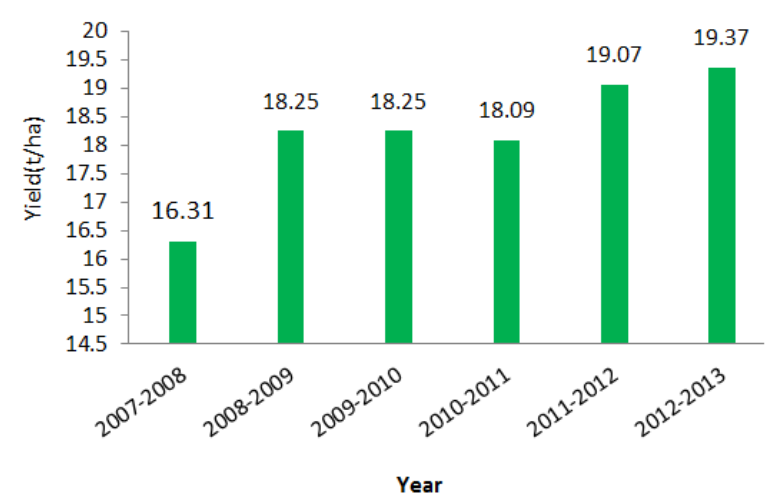

Figure 4. Yield status of potato in Bangladesh (FAOSTAT, 2014)

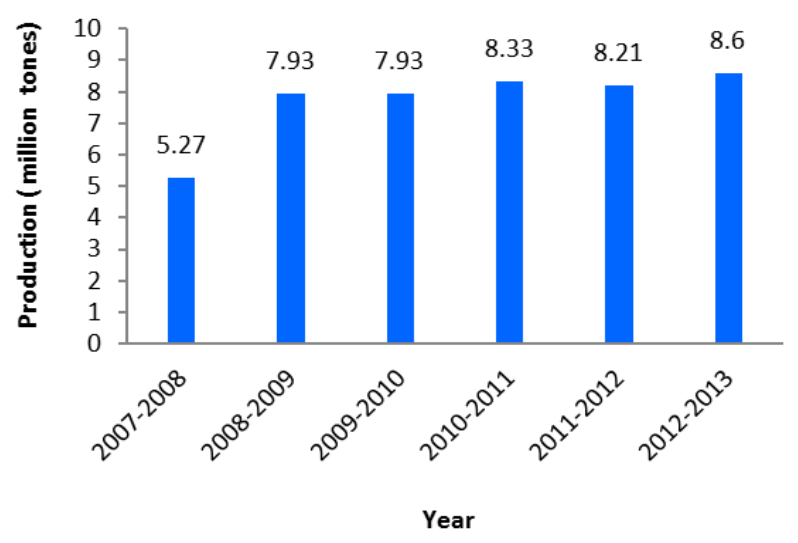

Figure 5. Production status of potato in Bangladesh (FAOSTAT, 2014)

Nevertheless, Bangladesh not only surpassed many of the developed countries, but also crossed most of the developing countries in production of potatoes. Upon analysis of the above Figs 1-5, it is evident that overall growth of potatoes in Bangladesh are positive in terms of area, production and yield except slight periodically fluctuation with yield and production. In the terminal year 2012-13, the combined effects of these three factors contributed to attain highest production of potatoes in Bangladesh which led to give so called "Potato Glut" in the country.

\subsection{The Potato Glut and Its Management}

When cereal production is plenty, it is called as the outcome of "Green Revolution". But the bumper production of potatoes in the country due to success in development of seed and seed based agronomic technologies, is called "Glut" undermining the success. This is actually a "Problem Plenty". When the country is struggling for food self-sufficiency and we get the surplus production with potatoes, also a food but non cereal one, we are not very happy and call it a "Glut" to designate as an unwanted problem. Nevertheless, the development of potato industry in the country must have to go via Glut. So, the Glut will be not a curse but a blessing for the country. It should be managed and used for the economic development of the country in the light of instances available globally.

\subsection{Potato Production by Divisions and Districts}

Actual growth in area, production and yield over the last ten years is presented in Fig 6 and Table 1. During the last eleven years, the area under potato expanded by $85 \%$ while production increased by $160 \%$. Evidently, the higher rate of growth in yield over the base year compensated the lower rate of growth in area to attain the ever biggest yield in the terminal year.

Potatoes are grown in all division and 64 districts of Bangladesh. But there exists significant yield variations amongst the districts which may appear from the Fig 6 and table-3, derived after [12]. It is evident that, the yields of potatoes in the north-western districts were less than that of mid Bangladesh districts despite having cooler agro-climate of the former agro-ecological belt which are considered more suitable for yield development. It may be concluded that the socio- economic and management factors contributed for higher yields of the latter districts. In this regard, achievement of Munshiganj district may particularly be mentioned. Nevertheless, the yield of Munshiganj has far surpassed the yields of all districts of the country. This achievement may be assigned to the skill and expertise in production of potatoes of the Munshiganj farmers. Higher yield is a pre-requisite for commercial agriculture and availability of low cost raw materials of potatoes for processing industries. So, production of potatoes may be considered suitable in most districts irrespective of climatic variations. There remain also scopes of yield equalization to some extent amongst the districts for furtherance of national production.

Table 1. Ranking of ten leading districts of Bangladesh in production of potatoes (Average of 2007-08 and 2008-09)

\begin{tabular}{|c|c|c|c|c|c|}
\hline SL No & District & Area (Ha) & Production (MT) & Yield (MT) & Rank \\
\hline 01 & Munshigonj & 34379 & 1031385 & 30.0 & 01 \\
\hline 02 & Rangpur & 53230 & 990197 & 18.63 & 02 \\
\hline $\mathbf{0 3}$ & Chandpur & 14653 & 272468 & 18.61 & 03 \\
\hline 04 & Comilla & 15942 & 294572 & 18.25 & 04 \\
\hline 05 & Rajshahi & 33275 & 591910 & 17.69 & 05 \\
\hline 06 & Thakurgaon & 23337 & 374802 & 15.94 & 06 \\
\hline 07 & Joypurhat & 37472 & 549352 & 14.59 & 07 \\
\hline 08 & Nilphamari & 23475 & 334804 & 14.23 & 08 \\
\hline 09 & Dinajpur & 39994 & 574706 & 14.23 & 08 \\
\hline 10 & Bogra & 63483 & 808583 & 12.71 & 09 \\
\hline
\end{tabular}

Source: [11]. 


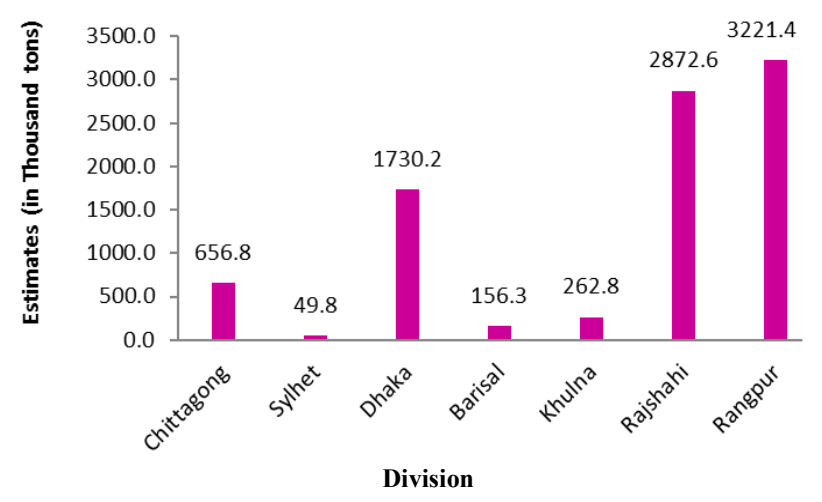

Figure 6. Estimation of potato per division in Bangladesh (BBS, 2012-2013)

\subsection{Scenarios of Global Per Capita Production and Consumption}

The production and consumption trend are going to raise day by day (Fig. $7 \& 8$ ). The food habit may changing in Bangladesh.

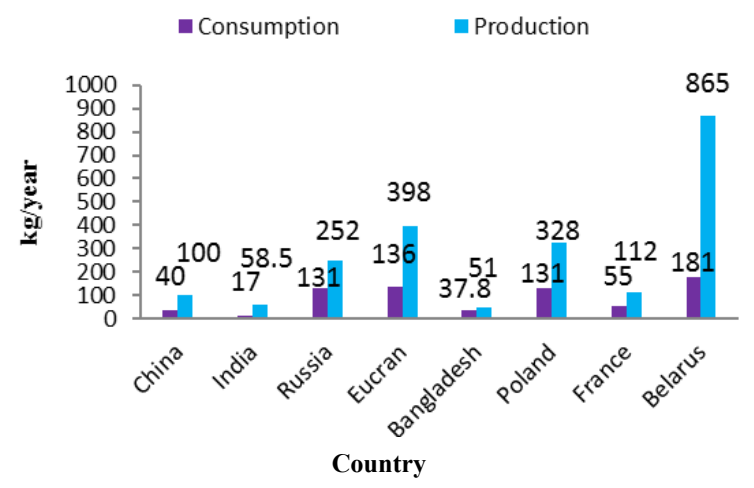

Figure 7. Production and consumption scenarios of major potato producing countries (PotatoPRO.com, 2008)

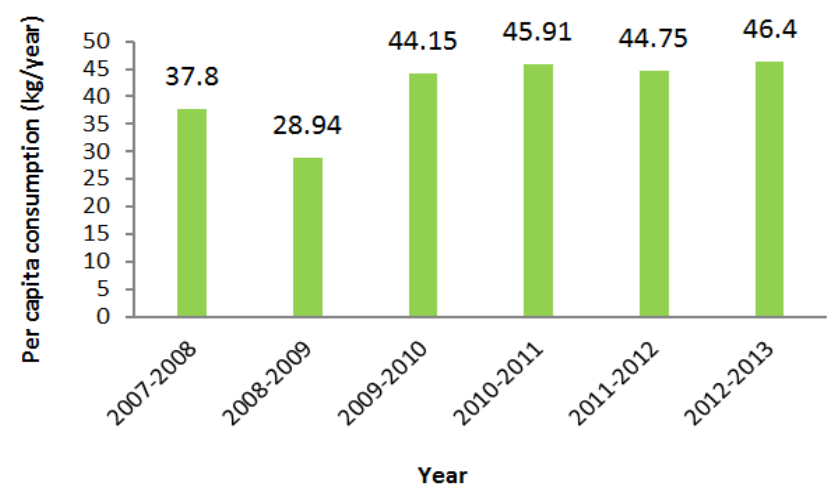

Figure 8. Consumption scenarios of potato in Bangladesh (PotatoPRO.com, 2008)

\subsection{Need for Export}
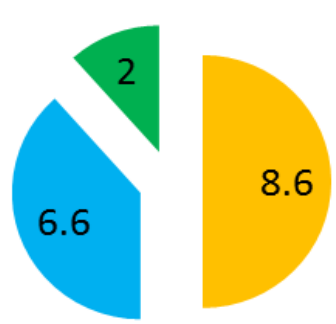

Total

Production

Total

demand

Surplus

Figure 9. Current status of potato in Bangladesh during 2014-15 (in million ton)

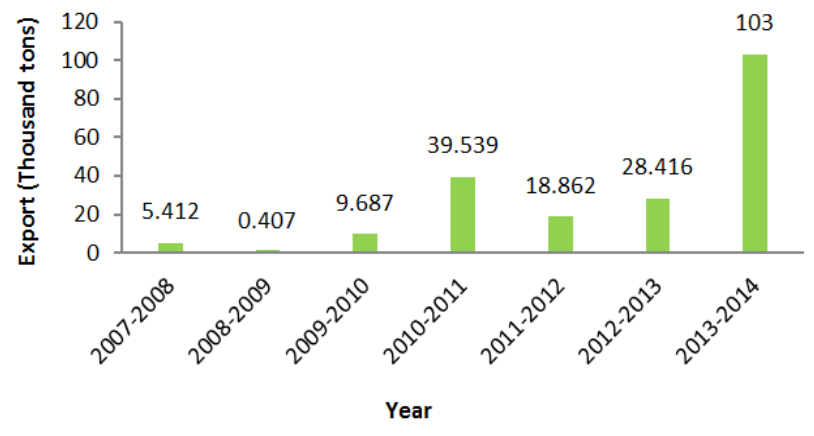

Figure 10. Export status of potato from Bangladesh (FAOSTAT, 2014)

Bangladesh produced 8.6million MT of potato during 2012-13 that made it the seventh largest producer in the [13]. The average productivity of potato in India is $19.37 \mathrm{t} / \mathrm{ha}$ which is more than the world average $(17.2 \mathrm{t} / \mathrm{ha})$. The per capita availability of potato has gone up to $37.8 \mathrm{~kg} /$ year from $5 \mathrm{~kg} /$ year in 1952; however, it is still far behind Ukraine (136 $\mathrm{kg} /$ year) Russian Federation (131 kg/year) and Belarus (181 $\mathrm{kg} /$ year) [14]. According to Directorate General of Food (DGoF), annual demand for potato in the country is 6.5-7.0 million tons against its production of 8.95 million tons (FY 2014). Potato is a perishable commodity and its harvest time (Feb/March) coincides with steep rise in temperature. From April onwards, temperatures start shooting up and the produce has either to be consumed within a short period or is required to be shifted to the cold stores. Due to inadequate, expensive and unevenly distributed refrigerated storage facilities, there are frequent gluts in the market causing substantial economic loss to the farmers and wastage of precious food. Such gluts have occurred every 2 to 3 years, whenever there had been an increase in potato production by $4-5 \%$ [5]. The glut years are followed by a reduction in potato area in the following year and the boom and bust cycle continues. Therefore, it is essential that potato consumption is increased to sustain this increase in production and to ensure remunerative prices to the farmers. Under the above existing circumstances, exporting of the bulky perishable potato into different foreign countries has increased. The demand for quality potato is increasing continuously for exporting foreign countries. 

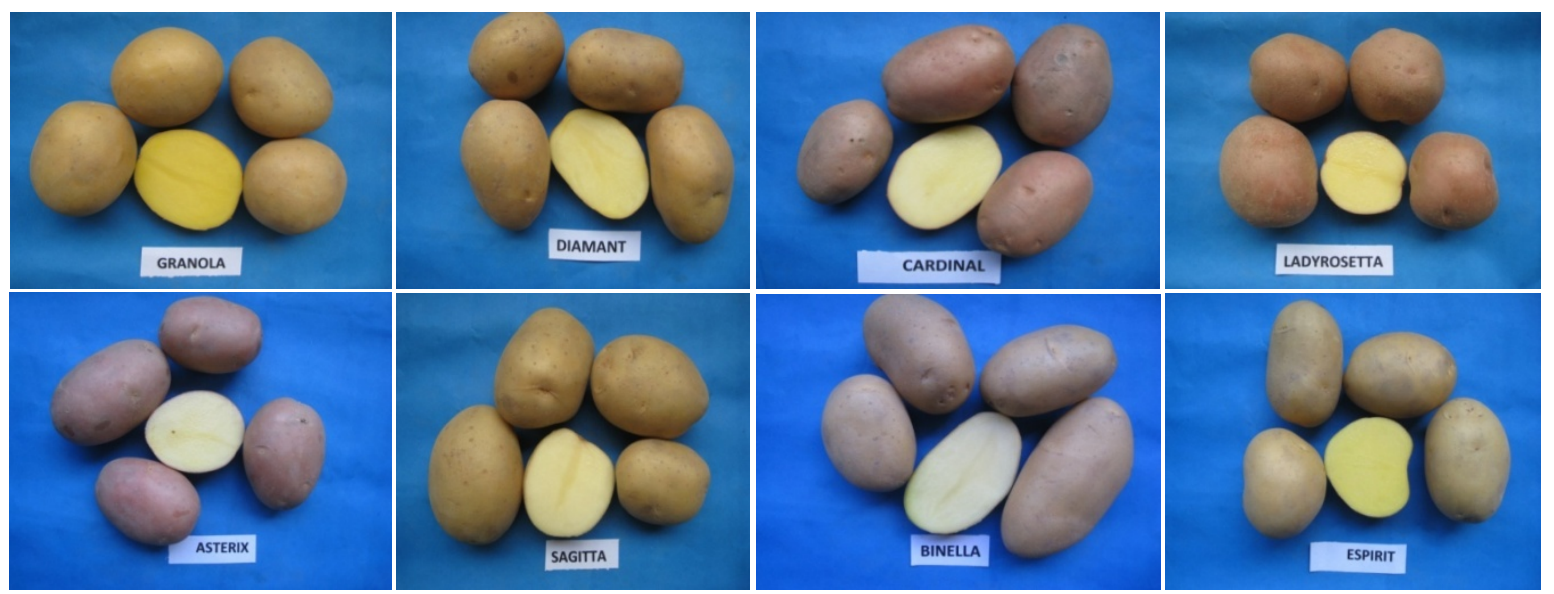

Plate 1. Some promising potato varieties in Bangladesh for export and processing industry

Table 2. Country wise Potato export from Bangladesh from 2008-09 to2013-14 (Value US\$)

\begin{tabular}{|c|c|c|c|c|c|c|}
\hline Country & $\underline{2008-09}$ & $\underline{2009-10}$ & $\underline{2010-11}$ & $\underline{2011-12}$ & $\underline{2012-13}$ & $\underline{2013-14}$ \\
\hline United arab emirates & - & 93534 & 466124 & 265545 & 429706 & 1964069 \\
\hline Belgium & - & - & - & - & - & 5156 \\
\hline Brunei darussai-am & - & - & 39416 & $4503 r$ & $786 \mathrm{t} 6$ & 77742 \\
\hline Bahrain & - & 16578 & 18132 & - & 14992 & 233819 \\
\hline Canada & - & 75 & - & - & - & 3025 \\
\hline Saint barthelemy & - & - & - & - & - & 6821 \\
\hline China & - & - & 6160 & - & - & - \\
\hline Cote d'ivoire & & & & & & 15495 \\
\hline Georgia & & & & & & 3025 \\
\hline France & & & & 2008 & & \\
\hline United kingdom & & & 3258 & 14733 & & \\
\hline Greece & & 9128 & & & & \\
\hline Hong kong & & & $\mathrm{s} 025$ & & $709 a$ & \\
\hline Indonesia & & & 1565409 & 572210 & 40082 & 150608 \\
\hline Japan & & & & & & 64551 \\
\hline Italy & t946 & 1195 & 60903 & & & \\
\hline Combodia & & & 49 & & 79409 & \\
\hline Kuwat & & 80479 & 200686 & 7772 & & 576269 \\
\hline Srilanka & & 94645 & 2187826 & 1085986 & 1375739 & 5067490 \\
\hline Myanmar & & 1811 & 95434 & $4 \mathrm{t} 304$ & 5116 & 4760 \\
\hline Maldives & & & 49315 & 25458 & & \\
\hline Malaysia & 64588 & 1909369 & 7242054 & 3495135 & 4736644 & 12355 \\
\hline Netherlands & & & & & & 11918246 \\
\hline Nepal & & & 2313 & & & \\
\hline Oman & & & 895 & 6784 & 19750 & 12354 \\
\hline Pakistan & & 1698 & & & $\mathrm{t} 286$ & 42839 \\
\hline Poland & & & 9529 & & & \\
\hline Qutar & & & & & 34680 & 286534 \\
\hline Russian federation & & 8109 & tloo692 & 294678 & $67979 \mathrm{t}$ & 8837811 \\
\hline Saudi araeiia & 255812 & 203623 & 258474 & 188623 & 440654 & 100954 \\
\hline Singapore & 364547 & tot2957 & 2667929 & 2401951 & 2627882 & 2761693 \\
\hline Senegal & & & & & 87245 & \\
\hline Thailand & & & & & & 17126 \\
\hline Suriname & & & & & $74 \mathrm{t} 47$ & \\
\hline Turki & & & & & & 6424 \\
\hline Togo & & & 64731 & & & \\
\hline United states & & 1301 & & & & \\
\hline Vietnam & & 29277 & 677313 & 50392 & 197229 & 236799 \\
\hline Total & 686892 & 3454651 & 16730794 & 8497610 & 10930066 & 32531912 \\
\hline
\end{tabular}

Source: Export Promotion Bureau, 2014. 


\section{Concluding Remarks}

Bangladesh is blessed with favorable agro-climate for production of potatoes all over the country but most favorably in the northern areas of this country. Its production can be increased with least efforts as against cereal food crops having almost touched the yield plateau. Apart from producing higher dry matter per unit area and per unit time, potato is a labor intensive crop. From our study, we found that in the context of production and export potato has a great prospect in Bangladesh. Considering all these advantages, potatoes can help attaining short and long term economic targets of the country and to face $21^{\text {st }}$ century challenges for "Digital Bangladesh" and to take part in world economy by attaining the developed country from low income situation for hunger free planets.

\section{Conflicts of Interest}

The author declares no potential conflict of interest about the present manuscript and author declares no part of this manuscript has been published elsewhere.

\section{Author's Contribution}

Tuhin Suvra Roy, helped by reviewing the manuscripts to become at present form and Rajesh Chakraborty, collected the data and literature from secondary sources for writing. Both authors were involved in manuscripts writing.

\section{REFERENCES}

[1] FAOSTAT. Statistical Database. Food and Agricultural
Organization of United Nations, Rome, Italy, 2014.

[2] Swaminathan, M. S. Food security and sustainable development. Current Science, 81(8), 948-954, 2001.

[3] Naik, P. S. Role of potato in food and nutritional security in developing countries with special reference to India. Cancer Imaging Program's Newsletter, 2, 5-8, 2005.

[4] Kumar, A and Pandey, S. K. Potato production: Harbinger of agricultural sustainability. Indian Farming 58(9): 3-7, 2008.

[5] Pandey,S. K, Khurana,S. M. P., Singh, S. V., Kumar, D. and Kumar, P. Evaluation of Indian and exotic potato varieties for sustaining processing industries in North Western plains of India. Indian J HortSci 62:155-159, 2005a.

[6] Bangladesh Bureau of Statistic (BBS). Agricultural Statistics Yearbook-2011, 2012.

[7] Schoenemann, J. A. Grading, packaging and Marketing potatoes, In: Potatoes production, storing processing, (Ed.). O. Smith. 2nd Edition. The AVI publishing company Inc., West port, pp. 470-505, 1977.

[8] Brown, C. R. Antioxidant in potato. Am. J. Potato Res., 82:163-72, 2005.

[9] Iritani, W. M. Growth and pre-harvest stress and processing quality of potatoes. Am. Potato J., 58: 71-80, 1981.

[10] Connor, C. J., Fisk, K. J., Smith, B. J. and Melton, L. D. Fat uptake in French fries as affected by different potato varieties and processing. J. Food Sci., 66: 903-908, 2001.

[11] Department of Agricultural Extension (DAE). Statistical data book-2009, p. 110, 2010.

[12] Rabbani, M. G., Siddique, M. A., Islam, M. M. and Islam, M. S. Potato Sector in Bangladesh: Its Challenges and Opportunities, KATALYST, 6, Baridhara, Dhaka-1212, 2010.

[13] FAOSTAT. Statistical Database. Food and Agricultural Organization of United Nations, Rome, Italy, 2013.

[14] FAOSTAT. Statistical Database. Food and Agricultural Organization of United Nations, Rome, Italy, 2008. 